\title{
ANALISIS KESALAHAN BERBAHASA PADA TEKS EKSPLANASI KOMPLEKS KARYA SISWA SEKOLAH MENENGAH ATAS
}

\author{
Noviardi Ari Saputra, Sumarwati, Muhammad Rohmadi \\ Universitas Sebelas Maret \\ Email : noveetra@gmail.com,watik_uns@ymail.com
}

\begin{abstract}
Abstrak: Penelitian ini bertujuan untuk mendiskripsikan dan menjelaskan: (1) ragam kesalahan berbahasa dalam teks eksplanasi kompleks karya siswa kelas XI MIPA 1 SMA Negeri 7 Surakarta, (2) kesalahan berbahasa yang paling dominan, (3) faktor penyebab terjadinya kesalahan berbahasa, dan (4) upaya guru untuk mengatasi penyebab kesalahan berbahasa dalam menulis teks eksplanasi kompleks karya siswa. Hasil penelitian ini adalah sebagai berikut. Pertama, terdapat empat unsur kesalahan berbahasa dalam teks eksplanasi kompleks karya siswa, yaitu: ejaan, diksi, kalimat, dan paragraf. Kedua, kesalahan berbahasa yang dominan dalam teks eksplanasi kompleks karya siswa adalah kesalahan bidang ejaan. Ketiga, kesalahan berbahasa Indonesia yang sering terjadi dalam teks eksplanasi kompleks karya siswa disebabkan oleh beberapa faktor antara lain: kurangnya waktu pembelajaran tentang ejaan akibat terintegrasi dengan materi bahasa Indonesia yang ada, kurang teliti dalam menulis, rendahnya motivasi siswa dalam pembelajaran menulis karena menulis dianggap sulit, serta kebiasaan siswa menulis tanpa memperhatikan EYD. Keempat, upaya yang dapat dilakukan untuk mengatasi penyebab kesalahan berbahasa dalam menulis teks eksplanasi kompleks antara lain: menambah waktu pembelajaan ejaan, meningkatkan kegiatan latihan menulis, menumbuhkan motivasi siswa dalam kegiatan menulis, serta meningkatan penguasaan siswa terhadap ejaan dan kaidah berbahasa.
\end{abstract}

Kata kunci: kesalahan berbahasa, analisis kesalahan, teks eksplanasi kompleks.

\section{LANGUAGE ERRORS ANALYSIS ON COMPLEX EXPLANATION TEXT OF SENIOR HIGH SCHOOL STUDENTS}

\begin{abstract}
The purpose of this study are to describe and explain: (1) the variety of language errors in complex explanation text of the student work of XI MIPA 1 SMA Negeri 7 Surakarta, (2) the most dominant language errors, (3) causes of error, and (4) teacher's effort to overcome the causes of language error in writing complex explanatory text of students. The results of this study are as follows. First, there are four elements of language errors in complex explanation text of the student work, namely: spelling, diction, sentence, and paragraph. Second, the dominant language errors in the complex explanatory text of the student work are a spelling mistake. Thirdly, language errors that often occur in the complex explanatory text of the student work is caused by several factors, as follows: lack of learning time about spelling due to integrated with existing Indonesian language materials, less thorough in writing, low motivation of students in writing because writing is difficult, as well as student habits of writing without regard to EYD. Fourth, efforts can be made to overcome the causes of language errors in writing complex explanatory texts, among others: increase the spelling time of spelling, increase writing exercises, foster student motivation in writing activities, and increase student mastery of spelling and language rules.
\end{abstract}

Keywords: language error, error analysis, complex explanation text.

\section{PENDAHULUAN}

Salah satu kegiatan manusia yang setiap hari dilakukan adalah berkomunikasi. Dalam berkomunikasi, manusia memerlukan alat yang dinamakan bahasa. Bahasa merupakan alat komunikasi yang berperan penting dalam 
kehidupan. Tidak ada kegiatan manusia yang tidak disertai oleh bahasa.

Sebagai sistem komunikasi, bahasa digunakan baik secara lisan maupun tulisan.Di Indonesia, Bahasa khususnya bahasa Indonesia, digunakan disegalabidang kehidupan.Sesuai dengan yang terkandung dalam UU Bahasa Nomor24 Tahun 2009 Pasal 25 Ayat 3 yang menyebutkan bahwa, "Bahasa Indonesia sebagai bahasa resmi negarasebagaimana dimaksud pada ayat (1) berfungsi sebagai bahasa resmi kenegaraan, pengantar pendidikan, komunikasi tingkat nasional, pengembangan kebudayaan nasional, transaksi dan dokumentasi niaga, serta sarana pengembangan dan pemanfaatan ilmu pengetahuan, teknologi, seni, dan bahasa media massa."

Perlu ditegaskan bahwa penggunaan bahasa Indonesia yang baik dan benar sesuai dengan kaidah yang berlaku merupakan cermin dari sikap pemakai bahasa tersebut terhadap bahasa Indonesia yang dipakainya. Jika bahasa Indonesia yang dipakai masih serampangan, menunjukkan bahwa pemakai bahasa masih kurang memiliki sikap positif terhadap bahasa Indonesia.Terampil dalam berbahasa mutlak diperlukan dan sangat penting untuk dikuasai oleh setiap orang. Sebagai contoh, dalam situasi yang tidak resmi atau santai tidak seharusnya digunakan bahasabaku,akan tetapi dalam situasi resmi harus digunakan bahasa Indonesia yang bersifat resmi atau bahasa baku.

Dalam lingkungan pendidikan, pembelajaran bahasa atau belajar berbahasa dapat diartikan yaitu belajar berkomunikasi, baik secara lisan maupun tertulis. Pada ragam lisan, informasi yang disampaikan dapat diperjelas dengan menggunakan intonasi, gerakan anggota tubuh tertentu, dan situasi tempat pembicaraan itu berlangsung. Pada ragam tulis unsur-unsur bahasa yang digunakan cenderung tidak selengkap unsur bahasa ragam lisan. Oleh sebab itu, agar informasi yang disampaikan secara tertulis menjadi lebih jelas, unsur-unsur bahasa yang digunakan harus lengkap. Bila unsur-unsur bahasa yang digunakan tidak lengkap, ada kemungkinan informasi yang disampaikan pun tidak dapat dipahami secara tepat.

Ada empat keterampilan bahasa yang harus diperhatikan dalam berbahasa yaitu keterampilan membaca, keterampilan berbicara, keterampilan menyimak, dan keterampilan menulis. Dari keempat keterampilan berbahasa tersebut, keterampilan menulis yang paling diabaikan. Pernyataan tersebut searah dengan pendapat Alwasilah (dalam Rohmadi, 2010: 4) mengatakan bahwa menulis merupakan mata pelajaran yang paling diabaikan, baik di sekolah lanjutan maupun di perguruan tinggi. Pembelajaran menulis di kelas lebih banyak berorientasi kepada kemampuan siswa untuk menyelesaikan butir-butir soal (ujian) terutama untuk mengejar target lulus Ujian Nasional (UN). Kreativitas dan produktivitas siswa dalam hal menulis sering diabaikan. Dengan kata lain, pembelajaran menulis di sekolah hanya mengutamakan hasil tanpa memperhatikan prosesnya. Hal tersebut tentu berdampak pada ketidakmampuan siswa dalam menulis. Kemampuan mereka kurang terasah sehingga siswa lebih sering mengeluh ketika diminta untuk membuat produk pembelajaran melalui tulisan.

Seseorang dapat mengungkapkan gagasan, pikiran, ide, pengetahuan, ilmu, danpengalaman melalui tulisan. Oleh karena itu,menulis juga merupakan suatu keterampilan yang produktif karena menghasilkan sesuatu.Di dalam kegiatan menulis,juga dipengaruhi oleh keterampilanproduktif lainnya, yaitu aspek berbicara maupun keterampilan reseptif yang terdiri dari aspek membaca danmenyimak serta pemahaman kosakata, diksi, keefektifan kalimat, penggunaan ejaan, pemahaman jenis paragraf dan tandabaca. Menulis merupakan keterampilan berbahasa yang paling penting dan sulit dikuasai.Namun 
demikian, pembelajaran menulis disekolah ternyata belum mempunyai tempat yang cukup. Pembelajaran menulis hanya mendapatkan porsi waktu yang kurang dibanding dengan pembelajaran kebahasaan yang lain seperti berbicara, membaca dan menyimak. Oleh sebab itu, tidak bisa di pungkiri bahwasanya setiap siswa dalam proses pembelajaran menulisakan mengalami kesalahan.

Keluhan mengenai rendahnya kemampuan menulis dikalangan siswa khususnya siswa sekolah menengah atas (SMA) merupakan salah satu masalah yang terjadi di dunia pendidikan.Dengan acuan tersebut, peneliti melakukan pra penelitian di SMA Negeri 7 Surakarta guna mengetahui kemampuan menulis siswa.Peneliti melakukan diskusi dengan guru mata pelajaran yang bersangkutan mengenai pembelajaran menulis di sekolah. Hasilnya, dalam Kurikulum 2013,salahsatu kompetensi dasar pembelajaran menulis siswa SMA yang dinilai sulit yaitu menulis teks eksplanasi kompleks, karena teks eksplanasi kompleks termasuk materi baru dalam Kurikulum 2013.

Selain itu, bukti nilai siswa masih menunjukkan nilai yang belum memuaskan. Ini berarti keterampilan menulis para siswa belum memadai.Berdasarkan hasil diskusi dan telaah pada teks eksplanasi kompleks karya siswa kelas XI tahun ajaran 2014/2015 dengan guru mata pelajaran yang bersangkutan, dari empat kelas XI MIPA 1, XI MIPA 2, XI MIPA 3, XI MIPA 4 ternyata kelas XI MIPA 1 memiliki tingkat kesalahan yang paling mendominasi. Kesalahan tersebut antara lain penulisan judul, penggunaan huruf kapital, penggunaan tanda baca, dan sebagainya.

Studi mengenai kesalahan dan hubungannya dengan pengajaran bahasa perlu digalakkan sebab melalui kegiatan analisis kesalahan itu dapat diungkapkan berbagai hal berkaitan dengan kesalahan berbahasa yang dilakukan oleh siswa atau pembelajar. Apabila kesalahan-kesalahan itu telah diketahui bentuk dan penyebabnya, sudah barang tentu dapat digunakan sebagai umpan balik dalam penyempurnaan pengajaran bahasa serta meningkatkan keterampilan dalam berbahasa. Hal itu seperti yang ditemukan oleh Ariningsih, Sumarwati, dan Saddhono (2012) bahwa peta kesalahan bahasa berfungsi sebagai bahan refleksi bagi guru untuk perbaikan pembelajaran berikutnya

Analisis kesalahan berbahasa memberikan banyak keuntungan terutama yang berhubungan dengan kegiatan pengajaran bahasa. Dengan analisis tersebut dapat diuraikan kesalahan apa saja yang terdapat dalam teks eksplanasi kompleks yang dibuat siswa kelas XI MIPA 1 SMA Negeri7 Surakarta.

\section{METODE PENELITIAN}

Penelitian ini dilaksanakan di SMA Negeri 7 Surakarta.Waktu pelaksanaan penelitian dilakukan selama enam bulan yaitu dari bulan Januari 2017 sampai dengan Juni 2017.Subjek penelitian ini yaitu siswa kelas XI MIPA 1 SMA Negeri7 Surakarta.

Penelitian ini merupakan penelitian kualitatif deskriptif.Data dan sumber data yang digunakan dalam penelitian ini berupa dokumen dan informan dengan menggunakan teknik purposive sampling.Data dikumpulkan dengan cara mengkaji teks eksplanasi kompleks karya siswa kelas XI MIPA 1 SMA Negeri7 Surakartadan melakukan in-dept interviewdengan beberapa siswa dan guru bahasa Indonesia untuk memperoleh data mengenai faktor penyebab terjadinya kesalahan pemakaian bahasa Indonesia serta upaya yang dilakukan guru untuk mengatasi kesalahan berbahasa tersebut. Selanjutnya, data divalidasi dengan menggunakan teknik trianggulasi dan review informan melalui analisis isi dengan empat tahap, yaitu pembentukan data, reduksi data, penarikan inferensi, dan analisis. 


\section{HASIL DAN PEMBAHASAN}

\section{Bentuk Kesalahan Bahasa}

Mengingat temuan kesalahan berbahasa Indonesia dalam penelitian ini cukup banyak, maka tidak semua jenis kesalahan yang ada dijelaskan di sini.D ari 28teks eksplanasi kompleks yang dianalisis, ditemukan adanya kesalahan bahasa baik dari aspek ejaan, diksi, kalimat, maupun paragraf.Selanjutnya, peneliti hanya menjelaskan beberapa kesalahan bahasa sebagai contoh.Berikut ini beberapa hasil temuan kesalahan bahasadalam teks eksplanasi kompleks karya siswa kelas XI MIPA 1 SMA Negeri7 Surakarta.

Data I

Contoh kesalahan:

Oleh sebab itu^hujan es jarang terjadi di daerah tropis seperti...

...dimulai ketika terjadinya revolusi industri di eropa, sejak saat...

Biasanya terjadi pada bulan desember.

Poin diatas merupakan beberapa penyebab terjadinya kelongsoran.

Dari beberapa contoh tersebut diketahui bahwa kesalahan ejaan yang sering dilakukan siswa yaitu kesalahan kesalahan pemakaian huruf kapital, kesalahan penggunaan tanda baca titik dan koma, dan kesalahan pada penulisan kata depan. Hal ini menunjukkan penguasaan kaidah bahasa siswa, khususnya ejaan masih kurang.

Data II

Contoh kesalahan:

Banjir adalah merupakanperistiwa yang terjadi ketika aliran air yang berlebihan...

...terjadi karena sesuatu hal yaitu seperti jebol tanggul, jebol bendungan, tanah longsor, hujan lebat di daerah sekitar hulu sungai, salju mencair masal secara tibatiba...

...busur spektrum warna besar berbentuk lingkaran yang terjadi karna pembiasan cahaya matahari oleh...

Badai adalah cuaca yang ekstrim, mulai dari hujan es dan badai salju sampai badai pasir...

... kerugian material, banyak puing - puing dan sampah yang terbawa...

Dari beberapa contoh tersebut, diketahui bahwa siswa banyak menggunakan kata tidak baku, kata-kata yang bersinonim dan kontras dan kata-kata yang tidak ekonomis. Adanya kesalahan diksi ini menunjukkan bahwa tingkat keterpahaman siswa dalam mengetahui kebakuan dan ketidakbakuan kata masih sangat kurang.

Data III

Contoh kesalahan

(1) Akibat lain dari pemanasan global adalah terpengaruhnya hasil pertanian, hilangnya gletser, dan punahnya berbagai jenis hewan.

(2) Perlu diketahui bersama bahwa hujan asam untuk pertama kalinya ditemukan pada 1852 oleh seseorang yang bernama Robert Angus Smith di kota Manchester.

(3) ...cara mencegah erosi pantai yaitu dengan penanaman pohon bakau dan membangun bangunan pemecah gelombang.

(4) Sampah itu sendiri dibagi menjadi dua jenis, dilihat dari sifatnya yaitu sampah organik dan juga sampah anorganik.

Keempat contoh kalimat tersebut termasuk kalimat yang tidak efektif. Contoh (1) adalah kalimat yang tidak ekonomis karena adanya kata dari pada frasa Akibat lain dari pemanasan global.. Seharusnya, frasa tersebut tidak perlu adanya kata depan dari sebagai penunjuk kepemilikan sehingga menjadi elum Akibat lain dari pemanasan global... Sama halnya dengan kalimat (1), kalimat (2) juga merupakan kalimat tidak ekonomis karena 
penggunaan kata-kata seseorang yang bernama pada frasa ...oleh seseorang yang bernama Robert Angus Smith di kota Manchester. Agar ekonomis kalimat tersebut seharusnya dibuat menjadi Perlu diketahui bersama bahwa hujan asam untuk pertama kalinya ditemukan pada 1852 oleh Robert Angus Smith di kota Manchester.

Adapun pada vontoh (3) adalah kalimat yang tidak memiliki kesejajaran makna,dan (4) adalah contoh kalimat yang tidak ekonomis. Kesalahan-kesalahan kalimat yang sering dilakukan siswa berdasarkan contoh tersebut menunjukkan bahwa siswa belum sepenuhnya mengerti tentang kalimat yang efektif.

Data IV

Contoh temuan:

(1) Gunung meletus merupakan peristiwa yang terjadi akibat endapan magma didalam perut bumi yang didorong keluar oleh gas yang bertekanan tinggi. Gunung berapi atau gunung api secara umum adalah istilah yang dapat didefinisikan sebagai suatu sistem saluran fluida panas (batuan dalam wujud cair atau lava) yang memanjang dari kedalaman sekitar $10 \mathrm{~km}$ di bawah permukaan bumi sampai ke permukaan bumi , termasuk endapan hasil akumulasi material yang dikeluarkan pada saat meletus.

(2) Erosi mempunyai dampak kebanyakan merugikan,karena terjadi kerusakan lingkungan.Menurut penelitian bahwa $15 \%$ permukaan bumi mengalami erosi. Kebanyakan disebabkan oleh erosi air kemudian erosi angin. Jika terjadi dipantai maka bentuk garis pantai akan berubah.
(3) Meskipun manfaat dari tenaga nuklir tampaknya merupakan pilihan yang jelas sebagai sumber daya masa depan, namun tenaga nuklir dapat berbahaya bagi lingkungan kita. Lingkungan kita tidak memiliki fitur untuk melindungi diri dari efek berbahaya dari limbah nuklir.

Bila dicermati dengan saksama, ketiga contoh paragraf tersebut termasuk paragraf yang tidak baik.Contoh (1) adalah paragraf yang tidak memiliki perpautan antarkalimat yang membangun paragraf sehingga menyebabkan kalimat-kalimat tersebut kurang padu dan kurang terpahami (tidak kohesif). Contoh (2) adalah paragraf yang tidak koheren. Sebab, paragraf yang koheren merupakan paragraf yang hanya mengembangkan satu gagasan pokok.Selanjutnya, contoh (3 adalah paragraf yang belum terkembang.Paragrafparagraf tersebut belum mampu mengungkapkan gagasan pokoknya secara jelas. Dengan kata lain, masing-masing paragraf itu masih menuntut hadirnya kalimat-kalimat penjelas.

\section{Faktor Penyebab Kesalahan}

Adanya kesalahan pemakaian bahasa Indonesia dalam teks eksplanasi kompleks karya siswa kelas XI MIPA 1 SMA Negeri7 Surakarta tidak lepas dari faktor penyebabnya. Faktor penyebab terjadinya kesalahan tersebut adalah sebagai berikut.

\section{Kurangnya ketelitian siswa}

Kurangnya ketelitian dalam menulis juga menjadi salah satu faktor penyebab kesalahan berbahasa di kalangan siswa.Kesalahan yang biasa terjadi karena ketidaktelitian, yaitu salah penulisan.Sebagian besar siswa yang menjadi narasumber mengatakan bahwa faktor yang mempengaruhi kesalahan dalam kegiatan menulis salah satunya adalah kurang teliti dan tidak sabar.Siswa cenderung ingin cepat selesai dalam mengerjakan tugas sehingga tidak 
memeriksa lagi apakah terdapat kesalahan penulisan atau tidak.Ketidaktelitian dalam menulis juga diungkapkan oleh guru sebagai salah satu faktor penyebab terjadinya kesalahan berbahasa.Siswa sering membuat kalimat yang panjang agar tulisan terlihat banyak sehingga inti kalimatnya menjadi tidak jelas. Jika siswa tersebut lebih teliti, seharusnya ia dapat membagi kalimat panjang tersebut menjadi beberapa kalimat agar intinya menjadi jelas.

\section{Kurangnya perhatian siswa}

Kebiasaan menulis tanpa memperhatikan EYD juga diungkapkan oleh narasumber, selaku guru bahasa Indonesia. Menurut guru, siswa cenderung mencampuradukan antara bahasa seharihari dengan bahasa tulis sehingga dalam proses kegiatan menulis, penulisan kaidah bahasa yang baku menurut EYD sering dikesampingkan dan sudah menjadi kebiasaan siswa menulis tanpa memperhatikan EYD. Beberapa siswa yang menjadi narasumber juga mengungkapkan bahwa bahasa sehari-hari sering terbawa dalam kegiatan menulis sehingga menyebabkan penulisan ejaan menurut EYD sering tidak diperhatikan.

\section{Rendahnya motivasi menulis.}

Faktor lain yang menyebabkan kesalahan pemakaian bahasa yakni kurangnya motivasi dalam menulis. Dalam kenyataannya, menulis menjadi kegiatan yang dianggap membosankan bagi siswa.Hal tersebut banyak diungkapkan oleh sebagian besar siswa yang menjadi narasumber.Sebagian besar siswa mengaku bahwa mereka tidak menyukai kegiatan menulis.Akan tetapi ada juga siswa yang menyukai kegiatan menulis.Sebagaimana yang diungkapkan guru yang bersangkutan, motivasi siswa dalam menulis masih sangat kurang.Hal tersebut disebabkan karena siswa beranggapan bahwa menulis itu sulit.

\section{Keterbatasan waktu menulis}

Kurangnya waktu pembelajaran tentang ejaan akibat terintegrasi dengan materi bahasaIndonesia yang ada. Dari hasil wawancara dengan guru yang bersangkutan, banyaknya kesalahan pada bidang ejaan salah satunya disebabkan karena pengajaran tentang ejaan terintegrasi dengan materi bahasa Indonesia yang ada. Guru juga menambahkan, di dalam kurikulum pun tidak ada materi yang mengkhususkan tentang pemakaian ejaan, materi tersebut terpadu hingga menjadi satu kesatuan yang utuh oleh materi pokok yang ada sehingga dalam mengajarkan materi pemakaian ejaan yang benar sangat sedikit karena harus berbagi waktu dengan materi pokok dalam bahasa Indonesia.

\section{Upaya Mengatasi}

Adanya kesalahan pemakaian bahasa Indonesia dalam teks eksplanasi kompleks yang dibuat siswa harus diatasi agar dikemudian hari tidak terjadi lagi kesalahan berbahasa yang sama. Paling tidak, kesalahan tersebut dapat dikurangi sekecil-kecilnya. Berikut ini beberapa upaya yang dapat dilakukan guru untuk mengurangi adanya kesalahan pemakaian bahasa Indonesiapada teks eksplanasi kompleks karya siswa.

\section{Meningkatan Penguasaan Kaidah Berbahasa}

Dari hasil wawancara peneliti kepada guru bahasa Indonesia dan siswa, diketahui salah satu cara agar penguasaan kaidah pemakaian bahasa dapat meningkat adalah dengan cara pemberian kembali materi tentang kaidah bahasa. Pemberian materi tentang kaidah bahasa harus dikhususkan dalam waktu tertentu agar siswa dapat benar-benar memahami pemakaian kaidah bahasa yang tepat dan juga agar kesalahan-kesalahan dalam menulis sebelumnya, tidak terulang lagi.Serta setiap awal pembelajaran menulis, siswa diingatkan kembali tentang kaidah bahasa.

\section{Menumbuhkan Motivasi Siswa dalam Kegiatan Menulis}

Menulis bisa dilakukan di manapun dan kapan pun. Kegiatan menulis tidak hanya dapat dilakukan saat kegiataan 
pembelajaran di sekolah berlangsung, tetapi kebanyakan siswa tidak pernah meluangkan waktunya di luar kegiatan sekolah untuk menulis.Mengantisipasi hal tersebut, guru diharapkan dapat menjadi motivator siswa dalam menulis. Guru harus lebih sering memberikan motivasimotivasi kepada siswa untuk sering melakukan latihan menulis. Dengan upaya tersebut diharapkan siswa termotivasi untuk lebih gemar dan benar-benar memahami tentang kebakuan bahasa dalam kegiatan menulis.

\section{Memperbanyak Latihan Menulis}

Menulis karangan seperti teks eksplanasi kompleks memerlukan penguasaan bahasa yang baik.Dari hasil wawancara dengan guru yang bersangkutan, dapat diketahui bahwa upaya yang dilakukan untuk mengatasi faktor penyebab kesalahan pemakaian bahasa adalah dengan meningkatkan latihan menulis melalui tugas lalu memantau tulisan siswa per tahapannya dan memberikan koreksi secara cermat tulisan yang dibuat siswa. Dengan seringnya melakukan latihan menulis, siswa akan semakin terampil dan teliti dalam menulis sehingga tulisan akan menjadi semakin baik.

\section{Menambah Waktu Pembelajaan Ejaan}

Pembelajaran ejaan di dalam kurikulum bahasa Indonesia selalu terintregrasi dengan materi yang ada. Materi tersebut terpadu hingga menjadi satu kesatuan yang utuh oleh materi pokok yang ada sehingga dalam mengajarkan materi pemakaian ejaan yang benar sangat sedikit karena harus berbagi waktu dengan materi pokok dalam bahasa Indonesia.Dari hasil wawancara peneliti kepada guru bahasa Indonesia, dapat diketahui bahwa salah satu upaya yang dilakukan adalah dengan menambah waktu pembelajaran ejaan baik diawal maupun diakhir materi pokok bahasa Indonesia.

Berdasarkan deskripsi pada hasil penelitian di atas dapat disusun pembahasan sebagai berikut ini.

\section{Bentuk-bentuk Kesalahan Berbahasa Indonesia yang Dominan}

Bentuk kesalahan berbahasa yang terdapat pada penelitian ini ada empat bidang, yaitu: a) kesalahan berbahasa dalam bidang ejaan, terdiri ataskesalahan penggunaan tanda baca, kesalahan penggunaan huruf kapital, dan kesalahan pada penulisan kata; b) kesalahan berbahasa dalam bidang diksi, terdiri atas penggunaan ketidaktepatan kata, dan penggunaan ketidaksesuaian kata; c) kesalahan berbahasa dalam bidang kalimat, terdiri atas kalimat yang tidak kohesif, kalimat yang tidak koheren, kalimat yang tidak memenuhi kesejajaran makna,dan kalimat yang tidak ekonomis; d) kesalahan berbahasa dalam bidang paragraf, terdiri atas paragraf yang tidak kohesif, paragraf yang tidak koheren, dan paragraf yang belum terkembang.

Kesalahan-kesalahan dalam bidang pemakaian bahasa Indonesia memang sering terjadi, terutama dalam bahasa tulis. Pada penelitian sebelumnya, Ariningsih, Sumarwati, dan Saddhono, (2012) juga menemukan bahwa masih banyak kesalahan bahasa dalam karangan siswa. Kesalahan-kesalahan tersebut berkaitan dengan penerapan kaidah ejaan, pilihan kata atau diksi, tata kalimat dan paragraf. Kesalahan-kesalahan tersebut berkaitan dengan penerapan kaidah ejaan, pilihan kata atau diksi, tata kalimat dan paragraf. Bahkan penelitian lainnya menemukan kesalahan ejaan selalu terjadi pada semua penulisan, baik yang dilakukan siswa, mahasiswa, maupun para karyawan (Aldena, Suryanto, \& Suhita, 2019).

\section{Kesalahan Ejaan Paling Banyak dilakukan Siswa}

Kesalahan ejaan adalah kesalahan yang paling banyak ditemukan dalam karangan siswa daripada kesalahan diksi,kalimat maupun paragraf. Pada penelitian sebelumnya pun Cahyaningrum (2010), Ariningsih, Sumarwati, dan 
Saddhono (2012), serta Heni (2014) juga menyimpulkan bahwa kesalahan ejaan adalah kesalahan pemakaian bahasa Indonesia yang paling dominan terjadi dalam wacana tulis jika dibandingkan kesalahan pemakaian bahasa Indonesia yang lain. Adanya kesalahan ejaan dari temuan tersebut tidak sesuai dengan Pedoman Umum Ejaan Yang Disempurnakan.Meskipun dalam buku tersebut sudah ada petunjuk bagaimana menggunakan ejaan yang tepat mulai dari kaidah penulisan huruf, penulisan kata, dan penggunaan tanda baca, siswa masih sering salah dalam menerapkannya.Padahal, adanya kesalahan ejaan juga dapat menjadikan kualitas tulisan itu kurang baik.

Keterbatasan dalam Penyampaian Materi Pemakaian Bahasa yang Baik dan Benar, serta Adanya Sikap Kurang Teliti Menjadi Penyebab yang Paling Mendominasi

Sebagian besar siswa mengalami kesalahan pemakaian bahasa Indonesia pada bidang ejaan, bahkan bisa dikatakan dari seluruh teks eksplanasikompleks siswa dominan mengalami kesalahan di bidang ejaan. Hal ini dirasa sangat wajar karena pengajaran tentang ejaan sangat sedikit. Waktu yang digunakan untuk mengajarkan tentang kaidah pemakaian bahasa Indonesia tentang ejaan sangat terbatas karena materi ejaan terintegrasi dengan mata pelajaran bahasa Indonesia yang sedang diajarkan. Dengan keterbatasan waktu tersebut menjadikan pemahaman tentang ejaan pun menjadi tidak maksimal.

Selain kesalahan di bidang ejaan, kesalahan lain juga ditemukan seperti kesalahan di bidang diksi, kalimat, dan paragraf. Munculnya kesalahan-kesalahan tersebut juga disebabkan karena faktor ketidaktelitian siswa dalam menulis.Siswa cenderung ingin cepat selesai dalam pembelajaran menulis sehingga tidak memeriksa lagi apakah terdapat kesalahan penulisan atau tidak. Hal yang sama juga ditemukan Sarwendah, Sumarwati, dan
Mulyono (2019) banyaknya kesalahan bahasa pada tulisan siswa lebih banyak disebabkan oleh faktor kekurangtelitian, Siswa juga sering membuat kalimat yang panjang agar tulisan terlihat banyak sehingga inti kalimatnya menjadi tidak jelas.

Beberapa faktor yang menjadi penyebab terjadinya kesalahan pemakaian bahasa Indonesia tersebut juga sesuai dengan penelitian yang dilakukan oleh Jalal (2012). Disebutkan bahwa terjadinya kesalahan pemakaian bahasa Indonesia disebabkan oleh beberapa faktor di antaranya, adanya keterbatasan dalam penyampaian materi pemakaian bahasa yang baik dan benar, serta adanya sikap kurang teliti dan kurang peduli dengan pemakaian kaidah-kaidah bahasa dalam tulisan, sehingga hasil penelitian ini sesuai dengan penelitian yang telah dilakukan oleh Jalal (2012).

\section{Pemberian Tugas Menulis adalah Solusi yang Tepat untuk Mengurangi} Kesalahan Pemakaian Bahasa Indonesia Adanya kesalahan-kesalahan tersebut harus segera diatasi dan diberikan upaya-upaya khusus agar kesalahan tersebut tidak terulang lagi. Salah satu upaya yang dapat dilakukan untuk mengatasi hal tersebut adalah dengan meningkatkan penguasaan kaidah pemakaian bahasa pada siswa oleh guru melalui pengajaran tentang penggunaan bahasa Indonesia yang baik dan benar. Upaya tersebut juga dilakukan para guru lain seperti yang ditemukan oleh Yikwa, Saddhono, \& Suryanto, (2019) di SMA YPK Kabupaten Nabire. Selain meningkatan penguasaan kaidah bahasa Indonesia, siswa juga harus meningkatkan latihan menulis.Untuk itu, solusi yang tepat untuk mengurangi terjadinya kesalahan struktur teks dan pemakaian bahasa Indonesia adalah dengan memberikan tugas-tugas menulis. Dengan sering memberikan tugas menulis, siswa akan semakin terampil dalam menulis.Tentunya, setiap pembelajaran 
menulis, guru memberikan pemahaman dengan cara yang menarik dan jelas sehingga siswa paham. Selain itu, guru juga memberikan koreksi terhadap hasil tulisan siswa sehingga siswa mengetahui kesalahannya dan dapat menulis dengan lebih baik lagi.

Dalam hal ini, Luthfiyati (2015) menyebutkan bahwa dengan meningkatkan pemahaman dalam pemakaian kaidah bahasa serta dengan peningkatan latihan menulis, merupakan beberapa upaya yang dapat dilakukan untuk mengatasi kesalahan pemakaian bahasa. Oleh karena itu, dapat disimpulkan bahwa hasil penelitian ini sama dengan hasil penelitian yang telah dilakukan oleh Luthfiyati (2015).

\section{SIMPULAN}

Simpulan hasil penelitian ini dapat dirumuskan sebagai berikut.Pertama, terdapat empat unsur kesalahan berbahasa dalam teks eksplanasi kompleks karya siswa, yaitu: ejaan, diksi, kalimat, dan paragraf. Kedua, kesalahan berbahasa yang dominan dalam teks eksplanasi kompleks karya siswa adalah kesalahan bidang ejaan.Ketiga, kesalahan berbahasa Indonesia yang sering terjadi dalam teks eksplanasi kompleks karya siswa disebabkan oleh beberapa faktor antara lain: kurangnya waktu pembelajaran tentang ejaan akibat terintegrasi dengan materi bahasa Indonesia yang ada, kurang teliti dalam menulis, rendahnya motivasi siswa dalam pembelajaran menulis karena menulis dianggap sulit, serta kebiasaan siswa menulis tanpa memperhatikan EYD. Keempat, upaya yang dapat dilakukan untuk mengatasi penyebab kesalahan berbahasa dalam menulis teks eksplanasi kompleks antara lain: menambah waktu pembelajaan ejaan, meningkatkan kegiatan latihan menulis, menumbuhkan motivasi siswa dalam kegiatan menulis, serta meningkatan penguasaan siswa terhadap ejaan dan kaidah berbahasa.

\section{REFERENSI}

Aldena, Y.A., Suryanto, E., \& Suhita, R. (2019). Kesalahan Berbahasa Indonesia pada Surat Dinas Desa Batan Sebagai Materi Ajar Bahasa Indonesia di SMP, Basastra; Jurnal Bahasa, Sastra, dan Pengajarannya, 7(2), 198-206

Ariningsih, N. A., Sumarwati, \& Saddhono, K.. (2012). Analisis Kesalahan Berbahasa Indonesia dalam Karangan Eksposisi Siswa Sekolah Menengah Atas. Basastra Jurnal Bahasa, Sastra Indonesia, dan Pengajarannya, 1(1), 130-141.

Cahyaningrum, W.T. (2010). Analisis Kesalahan Berbahasa pada Kaya Tulis Siswa Kelas XI SMA Negeri 1 Andong Kabupaten Boyolali. Skripsi Tidak Dipublikasikan, FKIP Universitas Sebelas Maret Surakarta.
Jalal, M. (2012). Problematika Kesalahan Bahasa Pada Penulisan Skripsi Mahasiswa Universitas Airlangga. Mozaik: Jurnal Ilmu Humaniora, 12 (2), Juli-Desember 2012, 92-209.

Kusumaningsih, dkk. (2013). Terampil Berbahasa Indonesia. Yogyakarta: ANDI

Luthfiyati, D. (2015). Mistakes in Writing Narrative Texts Made by The Students of Senior High School. JPH, Jurnal Pendidikan Humaniora, 3(2), 161-164

Mahsun.(2014). Teks dalam Pembelajaran Bahasa Indonesia. Jakarta: Rajawali Pers.

Markhamah \& Sabardila A. (2011). Analisis Kesalahan dan Karakteristik Bentuk Pasif. Surakarta : Jagat ABJAD.

Purwandari, H. S., Setiawan, B., \& Saddhono, K. (2014). Analisis 
Kesalahan Berbahasa Indonesia pada Surat Dinas Kantor Kepala Desa Jladri. Basastra Jurnal Bahasa, Sastra, Indonesia, dan Pengajarannya, 1 (3), 478-489.

Sarwendah, D., Sumarwati, \& Mulyono, S. (2019), Kesalahan Struktur Teks dan Kebahasaan Laporan Hasil Observasi: Studi Kasus di SMP Kristen 1 Surakarta, Basastra: Jurnal Bahasa, Sastra, dan Pengajarannya, 7(2), 43-48.

Slamet, St. Y. (2014). Problematika Berbahasa Indonesia dan Pembelajarannya.Yogyakarta: GRAHA ILMU.

Suwandi, S. (2008). Serbalinguistik (Mengupas Pelbagai Praktik Berbahasa). Surakarta: UNS Press.

Waridah, E. (2015). Pedoman Umum EYD: Ejaan yang Disempurnakan. Jakarta: Bmedia.

Yikwa, P., Saddhono, K., \& Suryanto, E. (2019). Kesalahan Pemakaian Bahasa Indonesia dalam Surat Resmi Tulisan Siswa SMA YPK Tabernakel Nabire, Basastra; Jurnal Bahasa, Sastra, dan Pengajarannya, 7(2), 119-128. 